Jurnal Mahasiswa BK An-Nur : Berbeda, Bermakna, Mulia

Volume 7 Nomor 3 Tahun 2021

Tersedia Online: https://ojs.uniska-bjm.ac.id/index.php/AN-NUR

p-ISSN. 2460-9722 | e-ISSN. 2622-8297

\title{
KEMAMPUAN KOMUNIKASI ORANGTUA DALAM MITIGASI LEARNING LOSS PADA ANAK DI KOTA TARAKAN
}

\author{
Emmy Ardiwinata ${ }^{1}$, Cici Ismuniar ${ }^{2}$ \\ ${ }^{1,2}$ Program Studi Bimbingan dan Konseling, Fakultas Keguruan dan Ilmu Pendidikan, Universitas Borneo \\ Tarakan \\ E-mail: ubt.emmy@gmail.com / 081214714760
}

\begin{abstract}
ABSTRAK
Partisipasi yang dapat orang tua lakukan selama anak BDR adalah membangun komunikasi yang baik dengan anak karena orang tua memegang peranan penting dalam membantu anak agar mencapai kompetensi sesuai level. Komunikasi orangtua pada anak memiliki makna bukan hanya pesan yang tersampaikan secara lisan namun juga memiliki muatan dukungan dan ungkapan kasih sayang. Penelitian ini bertujuan untuk melihat kemampuan komunikasi orangtua dalam mitigasi learning loss pada anak di Kota Tarakan. Indikator yang diukur yakni keterbukaan, empati, dukungan, rasa positif, dan kesamaan. Jenis penelitian ini merupakan penelitian kuantitatif. Alat pengumpul data yang digunakan adalah skala komunikasi untuk memperoleh data tingkat komunikasi orang tua. Subyek dalam penelitian ini adalah 260 orang tua siswa dari kelas 7 SMP Negeri di Kota Tarakan. Teknik analisis data yang digunakan adalah statistik deskriptif dan statistik inferensial. Dari data yang yang di dapat, dapat dianalisis bahwa orangtua di SMP Negeri Kota Tarakan sudah mampu berkomunikasi yang mumpuni dan dapat membantu anaknya dalam proses pembelajaran dari rumah.
\end{abstract}

Kata Kunci: Komunikasi; Learning Loss

\begin{abstract}
The participation that parents can do for SFH (Study from Home) children is to build good communication with children because parents play an important role in helping children to achieve competence according to level. Parental communication with children has meaning, not only messages conveyed orally but also containing support and expressions of affection. This study aims to examine the communication skills of parents in mitigating learning loss in children in Tarakan City. The indicators measured were openness, empathy, support, positivity, and equality. This type of research was a quantitative research. The data collection tool used was a communication questionnaire to obtain data on the communication level of parents. The subjects in this study were 260 parents of students from grade 7 SMP Negeri in Tarakan City. The data analysis technique used was descriptive statistics and inferential statistics. From the data obtained, it can be analyzed that parents at SMP Negeri Tarakan City were able to communicate well and can help their children in the learning process from home.
\end{abstract}

Keywords: Communication; Learning Loss

Dipublikasikan Oleh :

UPT Publikasi dan Pengelolaan Jurnal

Universitas Islam Kalimantan Muhammad Arsyad Al-Banjari Banjarmasin 


\section{Emmy Ardiwinata ${ }^{1}$, Cici Ismuniar ${ }^{2}$ \\ Jurnal Mahasiswa BK An-Nur : Berbeda, Bermakna, Mulia \\ Volume 7 Nomor 3 Tahun 2021 \\ Tersedia Online: https://ojs.uniska-bjm.ac.id/index.php/AN-NUR}

p-ISSN. 2460-9722 | e-ISSN. 2622-8297

\section{PENDAHULUAN}

Coronavirus Disease-19 (Covid-19) pertama kali ditemukan di Kota Wuhan China, virus ini dengan cepat menyebar ke seluruh dunia dan menjadikan status virus ini sebagai pandemi. Dalam upaya mengantisipasi penyebaran virus corona di Indonesia, Pemerintah segera melakukan sosialisasi dan himbauan untuk menerapkan protokol kesehatan dengan 3M (mencuci tangan, memakai masker, dan menjaga jarak). Salah satu cara agar virus ini tidak terus menyebar adalah dengan menjaga jarak yang membuat Menteri Pendidikan dan Kebudayaan mengeluarkan surat edaran nomor 4 tahun 2020 tentang Pelaksanaan Kebijakan Pendidikan dalam Masa Darurat Penyebaran Coronavirus Disease-19 (Covid-19) yang mengatur tentang pelaksanaan Belajar dari Rumah (BDR) agar tetap dapat memberikan pengalaman belajar yang bermakna bagi siswa selama masa pandemi. Proses pembelajaran kemudian bervariasi, dari BDR, tatap muka dengan protokol kesehatan yang ketat, dan campuran (BDRtatap muka) hal ini dilakukan sebagai upaya mitigasi learning loss berkepanjangan pada anak. Menurut Michelle Kaffenberger dari Universitas Oxford Inggris dalam Andriani dkk (2021), mengatakan bahwa dampak dari learning loss tidak akan berhenti sekalipun sekolah dibuka, jika tidak ada kebijakan terkait pemulihan kemampuan belajar terlebih dahulu.

FKIP Universitas Borneo Tarakan bersama Program Inovasi untuk Anak Sekolah Indonesia (INOVASI) memberikan sejumlah langkah strategis dalam mitigasi learning loss yaitu dengan bekerjasama dengan mengusulkan penggunaan kurikulum darurat, asesmen siswa pembelajaran terdiferensiasi, pelatihan dan pendampingan guru, serta partisipasi masyarakat. Partisipasi masyarakat dalam penelitian ini adalah partisipasi orangtua siswa pada jenjang pendidikan SMP Negeri dengan kemampuan komunikasi orangtua sebagai peranan penting dalam membantu anak agar mencapai kompetensi sesuai level selama anak BDR. Namun dalam pelaksanaan pembelajaran BDR, ditemukan fenomena sulitnya membangun komunikasi yang efektif antara orangtua dengan anak. Faktor yang mempengaruhi adalah orangtua yang mengeluhkan materi pelajaran anak yang sulit, beragam tugas dari guru yang dinilai merepotkan orangtua, penggunaan aplikasi pembelajaran dan gawai yang kurang familiar dan waktu orangtua yang terbatas dikarenakan harus bekerja baik dari rumah ataupun dari kantor sehingga anak memiliki kesulitan dalam melaksanakan BDR.
Menurut Sears (2004), komukasi yang efektif antara orangtua dan anak harus terbangun dengan baik karena komunikasi orangtua dan anak sangat penting bagi perkembangan kepribadian seorang anak. Suasana komunikasi orangtua di rumah mempunyai peranan penting dalam menentukan kehidupan anak di sekolah dan cara orangtua mendidik anak akan memberikan pengaruh terhadap kegiatan belajar anaknya. Orangtua yang kurang memperhatikan kemajuan pendidikan anak dapat menyebabkan anak kurang berhasil dalam belajarnya serta cara orangtua berbicara dan mendengarkan anak sangat mempengaruhi bagaimana anak berkomunikasi dengan orang lain.

Berdasarkan uraian tersebut, maka judul penelitian dalam ini adalah kemampuan komunikasi orangtua dalam mitigasi learning loss pada anak di Kota Tarakan.

\section{METODE}

Tipe penelitian ini menggunakan pendekatan kuantitatif yang sifatnya deskriptif yang memiliki tujuan untuk menggambarkan fenomena yang terjadi. Teknik pengambilan sampel yang digunakan dalam penelitian ini adalah simple random sampling dengan total responden sebanyak 260 orangtua siswa kelas 7 jentang pendidikan SMP di Kota Tarakan. Teknik pengumpulan data dalam penelitian ini menggunakan kuesioner dengan bantuan google form. Alat ukur yang digunakan adalah skala komunikasi berbentuk skala likert untuk mengukur sikap, pendapat, dan persepsi tentang fenomena sosial yang terdiri dari empat pilihan jawaban. Penelitian ini menggunakan uji validitas dan reliabilitas untuk mengukur ketepatan dan konsistensi pertanyaan yang diberikan dengan menggunakan alpha 5\% untuk meminimalkan tingkat kesalahan dalam penelitian. Kemudian teknik analsis yang digunakan untuk menganalisis data yang diperoleh dari hasil kuesioner yang diberikan melalui google form adalah teknik analisis statistik deskriptif dan statistik inferensial.

\section{HASIL DAN PEMBAHASAN}

Berdasarkan penelitian yang telah dilakukan terhadap orang tua siswa jenjang pendidikan kelas 7 diseluruh Sekolah Menengah Pertama Negeri (SMPN) di Kota Tarakan dengan jumlah sebanyak 260 orangtua siswa. Maka didapat data melalui melalui pengisian kuesioner, kemudian diberikan skor pada masing-masing item. Berikut adalah hasil analisis

Dipublikasikan Oleh :

UPT Publikasi dan Pengelolaan Jurnal

Universitas Islam Kalimantan Muhammad Arsyad Al-Banjari Banjarmasin 
Emmy Ardiwinata ${ }^{1}$, Cici Ismuniar ${ }^{2}$

Jurnal Mahasiswa BK An-Nur : Berbeda, Bermakna, Mulia

Volume 7 Nomor 3 Tahun 2021

Tersedia Online: https://ojs.uniska-bjm.ac.id/index.php/AN-NUR

p-ISSN. 2460-9722 | e-ISSN. 2622-8297

deskriptif dan hasil analisis inferensial data komunikasi orangtua siswa:

1. Hasil Analisis Statistik Deskriptif

Hasil penelitian komunikasi orangtua siswa setelah pengisian skala melalui google form. Maka peneliti dapat menjabarkan dari analisis statistik deskriptif dengan bantuan SPSS dapat dilihat pada Tabel 1.

Berdasarkan Tabel 1, hasil yang diperoleh dari uji statistik deskriptif pada 260 orangtua siswa diperoleh skor minimum 79 dan skor maksimum 128, sehingga rangenya 49. Jumlah skor 24976, standar deviasi/simpangan baju sebesar 7.616 dan variansi 58.004, standar deviasi dan variansi menunjukkan keberagaman data.

Adapun dilihat dari data skor hasil pengisian skala alam bentuk google form terkait dengan komunikasi orangtua siswa. Maka dikategorikan komunikasi orangtua siswa tersebut dapat dilihat pada Tabel 2.

Tabel 1. Deskripsi Komunikasi Orangtua Siswa

\begin{tabular}{|c|c|c|c|c|c|c|c|c|c|}
\hline & \multirow{2}{*}{$\frac{\mathbf{N}}{\text { Statistic }}$} & \multirow{2}{*}{$\begin{array}{c}\text { Range } \\
\text { Statistic }\end{array}$} & \multirow{2}{*}{$\frac{\text { Min }}{\text { Statistic }}$} & \multirow{2}{*}{$\frac{\text { Max }}{\text { Statistic }}$} & \multirow{2}{*}{$\frac{\text { Sum }}{\text { Statistic }}$} & \multicolumn{2}{|c|}{ Mean } & \multirow{2}{*}{$\begin{array}{c}\begin{array}{c}\text { Std. } \\
\text { Deviation }\end{array} \\
\text { Statistic }\end{array}$} & \multirow{2}{*}{$\frac{\text { Variance }}{\text { Statistic }}$} \\
\hline & & & & & & Statistic & $\begin{array}{c}\text { Std. } \\
\text { Error }\end{array}$ & & \\
\hline \multirow{2}{*}{$\begin{array}{l}\text { Komunikasi } \\
\text { Valid N } \\
\text { (listwise) }\end{array}$} & 260 & 49 & 79 & 128 & 24976 & 96.06 & 0.472 & 7.616 & 58.004 \\
\hline & 260 & & & & & & & & \\
\hline
\end{tabular}

Tabel 2. Kategori Komunikasi Orangtua Siswa

\begin{tabular}{cccccc}
\hline & & Frequency & Percent & Valid Percent & Cumulative Percent \\
\hline \multirow{4}{*}{ Valid } & Rendah & 53 & 20.4 & 20.4 & 20.4 \\
& Sedang & 207 & 79.6 & 79.6 & 100.0 \\
& Total & 260 & 100.0 & 100.0 & \\
\hline
\end{tabular}

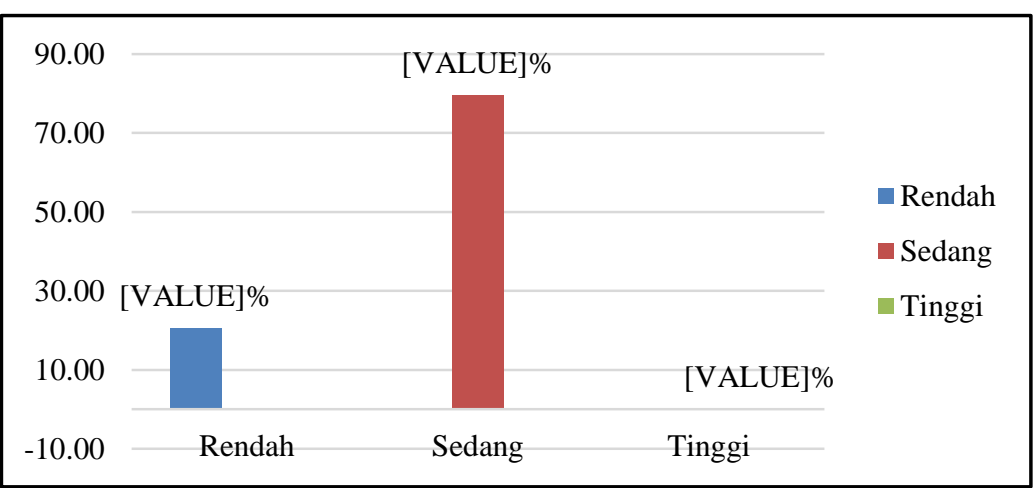

Gambar 1. Grafik Persentase Komunikasi Orangtua Siswa

Berdasarkan Grafik 1, hasil yang diperoleh untuk kategori rendah komunikasi orangtua siswa yaknik sebanyak $20.40 \%$ dan untuk kategori sedang komunikasi orangtua siswa yaknik sebanyak $79.60 \%$ sedangkan untuk kategori tinggi komunikasi orangtua siswa yakni sebanyak $0.00 \%$.
2. Hasil Analisis Statistik T-Test Perhitungan uji-t dalam penelitian ini, penulis menggunakan SPSS sehingga memudahkan penulis dalam menghitung uji-t dapat dilihiat pada Tabel

\section{Dipublikasikan Oleh :}

UPT Publikasi dan Pengelolaan Jurnal 
Emmy Ardiwinata ${ }^{1}$, Cici Ismuniar ${ }^{2}$

Jurnal Mahasiswa BK An-Nur : Berbeda, Bermakna, Mulia

Volume 7 Nomor 3 Tahun 2021

Tersedia Online: https://ojs.uniska-bjm.ac.id/index.php/AN-NUR

p-ISSN. 2460-9722 | e-ISSN. 2622-8297

Tabel 3. Uji T (One-Sample Test)

\begin{tabular}{ccccccc}
\hline & \multicolumn{4}{c}{ Test Values $=\mathbf{0}$} \\
\cline { 2 - 6 } & T & Df & $\begin{array}{c}\text { Sig. }(2- \\
\text { tailed })\end{array}$ & $\begin{array}{c}\text { Mean } \\
\text { Difference }\end{array}$ & \multicolumn{2}{c}{$\begin{array}{c}\text { 95\% Confidence Interval of } \\
\text { the Difference }\end{array}$} \\
\hline Komunikasi & 203.380 & 259 & 0.000 & 96.062 & 95.13 & Lower \\
\hline
\end{tabular}

Berdasarkan Tabel 3, hasil uji t diketahui nilai signifikansinya (p) 0.000 dan nilai tersebut lebih kecil dari $0.05(\mathrm{p}<0.05)$, hasil tersebut dapat disimpulkan bahwa kemampuan komunikasi orangtua siswa memiliki pengaruh dalam mitigasi learning loss.

\section{PEMBAHASAN}

Saat ini pelaksanaan bimbingan belajar yang seyogyanya di sekolah berubah menjadi di rumah menjadikan peran guru dialihkan ke orangtua. Pola pelaksanaan yang berubah ini mengharuskan orangtua memahami metode pelaksanaan bimbingan dan pendampingan belajar. Dalam hal ini, diperlukan komunikasi yang efektif antara orangtua dengan anak agar dalam proses belajarnya merasa aman dan nyaman, sehingga anak dapat lebih fokus pada materi pembelajaran.

Menururt Devito (2013), terdapat lima aspek yang perlu ada dalam berkomunikasi yaitu: Keterbukaan, Empati, Dukungan, Perasaan Positif dan Kesamaan. Berdasarkan hasil penelitian yang telah dilakukan maka lima aspek berkomunikasi yang dimiliki oleh orangtua siswa SMP Negeri di Kota Tarakan sudah masuk kedalam kategori sedang. Hal ini cukup baik karena orangtua dapat membantu anak untuk dapat berbagi perasaan, merasa ada, dan merasakan dukungan dari orangtua disaat anak sedang mengalami kesulitan dalam belajar. Memberikan semangat dan dukungan secara intens perlu dilakuan orangtua karena pada kondisi seperti ini anak diwajibkan melakukan pembelajaran secara mandiri sehingga anak terkadang jenuh dengan metode pembelajaran BDR.

Menurut Huong dan Jatturas (2020), learning loss (kehilangan belajar) telah terjadi secara progresif karena lebih dari dua pertiga dari total pelajar di seluruh dunia telah mengalami gangguan belajar secara langsung dan tidak langsung dalam tiga bulan terakhir. Kehilangan belajar ini mengacu pada "hilangnya pengetahuan dan keterampilan secara spesifik atau umum atau pembalikan dalam kemajuan akademis, paling umum karena kesenjangan yang diperpanjang atau diskontinuitas dalam pendidikan siswa".

Kemampuan komunikasi antara orangtua dan anak pada masa BDR saat ini diharapkan dapat memitigasi learning loss atau hilangnya kemampuan belajar pada anak. Dari data yang telah diperoleh pada Gambar 1, dapat dikatakan bahwa orangtua di SMP Negeri Kota Tarakan sudah mampu berkomunikasi yang mumpuni dengan anak, dapat membantu anaknya dalam proses pembelajaran dari rumah. Walaupun fenomena yang terjadi di lapangan didapatkan bahwa fokus konsentrasi orangtua terbagi antara mendampingi anak dan juga pada pekerjaan sehari-hari.

Dalam upaya mendukung pelaksanaan BDR agar siswa/i tidak terdampak learning loss, maka ada beberapa cara yang dapat dilakukan orangtua agar anak tidak mengalami learning loss pada pembelajaran jarak jauh Pratiwi (2021), yaitu: (1) Membuat jadwal rutin seperti ketika masih sekolah tatap muka, (2) Orangtua menjadi pusat monitoring anak, (3) Penugasan materi, (4) Aktif berkomunikasi dengan guru.

Sehingga orangtua dapat memastikan anak mendapatkan pendidikan yang baik dan maksimal walau proses belajar dilakukan dari rumah. Pada akhirnya, tugas mendidik anak bukan hanya menjadi tanggungjawab pihak sekolah, di masa pandemi ini tugas pembelajaran juga menjadi tanggungjawab orangtua untuk memastikan anak-anak tidak menjadi salah satu anak yang terkena dampak learning loss.

\section{PENUTUP}

Berdasarkan hasil penelitian "Kemampuan Komunikasi Orangtua dalam Mitigasi Learning Loss pada Anak di Kota Tarakan", maka kesimplan yang diperoleh adalah orangtua yang memiliki anak bersekolah di jenjang SMP Negeri di Kota Tarakan sudah mampu berkomunikasi yang mumpuni dengan skor $79.60 \%$ dimana ini salah satu bentuk komunikasi efektif yang dimiliki orangtua sehingga dapat membantu dan mendukung anak selama pola pembelajaran dari rumah yang berlangsung di masa pandemi Covid-19. Adapun saran yang diharapkan

Dipublikasikan Oleh :

UPT Publikasi dan Pengelolaan Jurnal

Universitas Islam Kalimantan Muhammad Arsyad Al-Banjari Banjarmasin 
Emmy Ardiwinata ${ }^{1}$, Cici Ismuniar ${ }^{2}$

Jurnal Mahasiswa BK An-Nur : Berbeda, Bermakna, Mulia

Volume 7 Nomor 3 Tahun 2021

Tersedia Online: https://ojs.uniska-bjm.ac.id/index.php/AN-NUR

p-ISSN. 2460-9722 | e-ISSN. 2622-8297

bagi peneliti selanjutnya mampu menyasar subjek dan lingkup yang lebih luas serta dapat dilakukan sosialisasi atau pendampingan lebih lanjut secara individu maupun kelompok kepada orangtua siswa dengan memanfaatkan layanan-layanan dalam bimbingan dan konseling.

\section{REFERENSI}

Andriani, W., Subandowo, M., Karyono, H., \& Gunawan, W. (2021). Learning Loss dalam Pembelajaran Daring di Massa Pandemi Corona. Prosiding Seminar Nasional Teknologi Pembelajaran Universitas Negeri Malang, 489.

Azwar, S. (2008). Reliabilitas dan Validitas. Yogyakarta: Pustaka Pelajar.

Devito, J. A. (2013). The Interpersonal Communication Book. New York: Pearson.

Effendy, O. U. (2000). Ilmu Teori dan Filsafat Komunikasi. Bandung: PT. Citra Aditya Bakti.

Glossary, T. (2013, Agustus 29). Learning Loss. Retrieved from The Glossary Of Education Reform: https://www.edglossary.org/learning-loss/

Huong, L. T., \& Jatturas, T. N. (2020, Mei 18). The Covid-19 Induced Learning Loss - What Is It And How It Can Be Mitigated? Retrieved from UKFIET The Education And Development Forum: https://www.ukfiet.org/2020/the-covid-19induced-learning-loss-what-is-it-and-how-itcan-be-mitigated/

Prasetyo, M. (2000). Kesehatan Mental Anak Dalam Keluarga. Semarang: FIP UNNES.

Pratiwi. (2021). Dinamika Learning Loss: Guru dan Orang Tua. Jurnal Edukasi Nonformal, 146

Sears, W. (2004). Anak Cerdas: Peran Orang Tua Dalam Mewujudkannya. Jakarta: Emerald Publishing.

Sugiyono. (2017). Pendekatan Kuantitatif, Kualitatif, dan $R \& D$. Bandung: Alfabeta.

Dipublikasikan Oleh :

UPT Publikasi dan Pengelolaan Jurnal

Universitas Islam Kalimantan Muhammad Arsyad Al-Banjari Banjarmasin 